\title{
The diversity of useful plants and botanical knowledge of the Rejang Tribe in Kepahiang District, Bengkulu Province, Indonesia
}

\author{
WIRYONO $^{1, \bullet}$, SRIWAHYUNI ${ }^{1}$, GUSTI AYU WINANDA ${ }^{1}$, SAPRINURDIN ${ }^{1}$, STEFFANIE NURLIANA $^{2}$ \\ ${ }^{1}$ Department of Forestry, Faculty of Agriculture, Universitas Bengkulu. Jl. WR Supratman, Kandang Limun, Bengkulu 38122, Bengkulu, Indonesia. \\ Tel./fax.: +62-736-21170, `email: wiryonogood@unib.ac.id,wiryonogood@yahoo.com. \\ ${ }^{2}$ Department of Biology, Faculty of Mathematics and Natural Sciences, Universitas Bengkulu. Jl. WR Supratman, Kandang Limun, Bengkulu 38122, \\ Bengkulu, Indonesia
}

Manuscript received: 1 October 2019. Revision accepted: 18 November 2019.

\begin{abstract}
Wiryono, Sriwahyuni, Winanda GA, Saprinurdin, Nurliana S. 2019. The diversity of useful plants and botanical knowledge of the Rejang Tribe in Kepahiang District, Bengkulu Province, Indonesia. Biodiversitas 20: 3599-3607. The rural people derive multiple benefits from the highly diverse plants in their traditional gardens and the nearby natural forests. However, the conversion of natural forests and traditional gardens into monoculture plantations in many areas has reduced the plant diversity, which in turn has also reduced the botanical knowledge, especially among the younger generation. This study was conducted to know: (i) the diversity of plant species used by the people of Rejang tribe in Kota Agung Village, Kepahiang District, Bengkulu Province, Indonesia, (ii) the correlation between age and botanical knowledge, and (iii) the effect of gender on the botanical knowledge. Data were collected through interviews with five key informants and 68 villagers, and the data were analyzed qualitatively and quantitatively using t-test and regression analyses. The results showed that the Rejang people in Kota Agung Village used 130 plant species for 12 different purposes. The three top use categories were food, medicine, and ornament. The botanical knowledge was positively correlated with age, and women had better botanical knowledge than men, presumably due to the longer time they spend in taking care of the homegardens. This study confirms the worldwide trend that there is a decline in botanical knowledge among young people.
\end{abstract}

Keywords: Agroforestry, biodiversity, ethnobotany, TEK, traditional gardens

\section{INTRODUCTION}

Rural people around the world have benefited from natural forests and traditional gardens for their daily needs. Approximately 1.6 billion rural people in the world are dependant on forests to varying degree, while 60 million indigenous people rely completely on forests for their livelihoods, and about 1.2 billion people in developing countries use agroforestry systems to meet their daily needs and also to get income (Cholchester et al. 2006). The indigenous people living near the tribal forest called Hiang Forest of Kerinci District, Jambi Province used 48 forest plant species for six types of uses (Andesmora et al 2017), while the local people near the Gunung Halimun National Park, West Java, used 76 plant species from the forest for five major use categories (Hidayat and Fijridiyanto 2002).

Like natural forests, agroforestry systems also provide ecosystem services, environmental benefit and economic commodities (Jose 2009). Agroforestry system has been practiced by rural people around the world, in various forms of traditional gardens (King 1987). Having both seasonal and perennial plants, traditional gardens have high diversity of plants that provide many plant products to rural people. In Basketo Special Woreda of Southwestern Ethiopia, 149 species of plants were planted in home gardens for various uses (Woldeyes et al. 2016). In villages of Leyte island of the Philippines, people used 122 plant species for various purposes (Langenberger et al. 2009). In villages adjacent to the Lore Lindu National Park, Central Sulawesi,
149 crop species were identified from homegardens, mainly fruit, vegetable, spice, or medicinal plants (Kehlenbeck and Maass 2004). In Bustamante, in the northern region of the State of Nuevo León, Mexico, 218 useful species were recorded from private and public gardens which were employed for eight major uses (Estrada-Castillón et al. 2018). The rural community of Bananal, Mato Grosso, Brazil, used 152 species from the natural vegetation and agricultural land for six major uses (Miguéis et al. 2019).

However, the high plant diversity is jeopardized by the decline of natural forest areas worldwide due to conversion to plantations and other land uses. According to FAO (2016), the annual global deforestation rate was 10.6 million for the period of 1990 to 2000 , and 6.5 million from 2010 to 2015. Indonesia ranked first in deforestation rate in 2012 (Darmawan et al. 2016). Much of natural forests in Indonesia has been converted into oil palm plantations (Saxon and Roquemore 2011). Another cause of plant diversity loss is the conversion of traditional gardens to the modern ones. In the past, traditional gardens were planted with various annual and perennial plants, so they resembled natural forests in structure and provided many needs for rural people (Soemarwoto 1983; Iskandar and Iskandar 2016). The modern homegardens has simpler structure and lower diversity (Iskandar et al. 2018; Prihatini et al. 2018).

The loss of natural forests and other ecosystems due to economic development not only reduces biodiversity but also local botanical knowledge (Ramirez 2007). The 
decline of botanical knowledge among the young generation has been found in Kolo District, Southwestern Niger (Ayantunde et al. 2008), in a horticultural village in Dominica (Quinlan and Quinlan 2007), in Zapotec communities in Mexico (Saynez-Vazquez et al. 2016), in Parnaíba Delta, Brazil (Sousa et al. 2012), in Bengkulu Province, Indonesia (Wiryono et al. 2017; Wiryono et al. 2019), and in Subang District, West Java, Indonesia (Suryana et al. 2018).

The loss of local botanical knowledge among the youth has become a serious concern (Ramirez 2007; Aswani et al. 2018), as ethnobotanists believe that such traditional knowledge is the science of survival (Aiona et al. 2007). Studies have been conducted to know the factors that are contributing to that loss. It is encouraging that in some communities, young generation still maintains their botanical knowledge because they continue using traditional plant products (Vandebroek and Balick 2012, Gómez-Baggethun and Reyes-Garcia 2013).

Only a few studies on the status of botanical knowledge have been undertaken in Indonesia, such as in villages near Wakatobi Marine National Park in southeast Sulawesi (Pilgrim et al. 2008), in Serawai tribe in Bengkulu City (Putra et al. 2012), in Lembak Tribe in Central Bengkulu (Wiryono et al. 2017), in Semende tribe in Kaur District,
Bengkulu (Wiryono et al. 2019) and in Subang District, West Java (Suryana et al. 2018). More such studies covering other tribes are needed in Indonesia. Therefore, this present study was conducted to know the diversity of plant species used by the people of Rejang tribe in Kepahiang District, Bengkulu Province, Indonesia, the correlation between age and botanical knowledge, and the effect of gender on the botanical knowledge.

\section{MATERIALS AND METHODS}

\section{Study area}

This study was conducted in Kota Agung Village, Bermani Sub-district, Kepahiang District, Bengkulu Province, Indonesia (Figure 1). The village is located at approximately $400 \mathrm{~m}$ altitude, having annual rainfall of $2800 \mathrm{~mm}$, relative humidity of $85 \%$ and temperature of $24^{\circ} \mathrm{C}$. (BPS Kepahiang 2018). The majority of villagers belong to the Rejang Tribe. In daily life, they speak Rejang language, but in formal situation, they speak Indonesian. Most people work as farmers. They plant coffee and paper in their plantation. The diversity of plants is found mostly in homegardens.

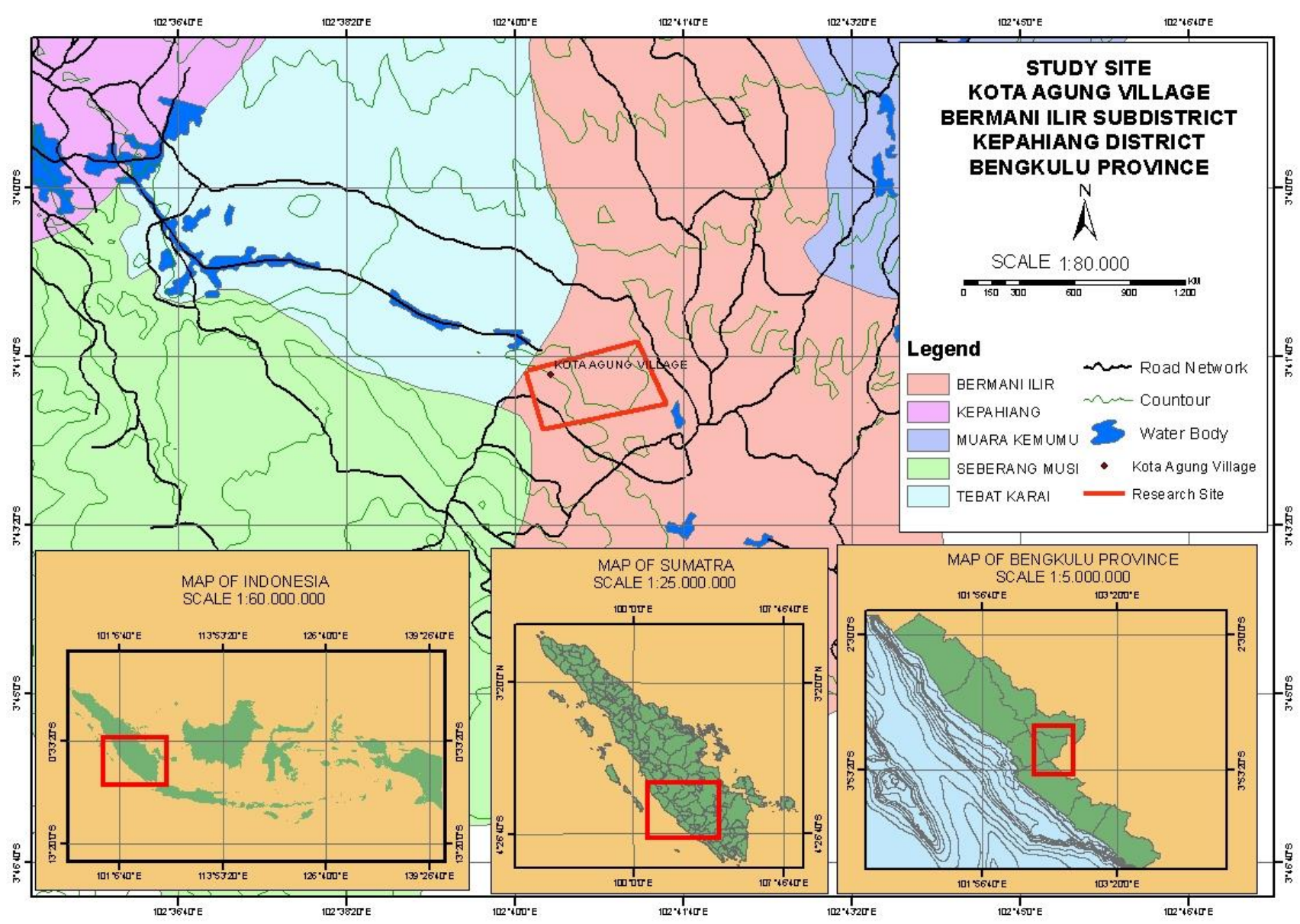

Figure 1. Location of study in Kota Agung Village, Bermani Ilir Sub-district, Kepahiang District, Bengkulu Province, Indonesia 


\section{Data collection}

Gathering data of locally useful plants

Data of useful plants were collected by surveying homegardens and coffee plantations with five key informants, one informant at a time of survey, and interviewing them about the use of each plant species. The informants were the villagers who had a better knowledge of plant names and uses than the ordinary people. Snowball method was used to select the key informants. In ethnobotanical studies, gathering data is commonly done by interviewing key informants (Tongco 2007).

A total of 130 locally useful plant species were found mostly in the homegardens, each of which was photographed. Of the 130 species, 50 were selected to be shown to respondents to test their knowledge of plant names and uses.

\section{Gathering data of local botanical knowledge}

Sixty-eight respondents, out of 459 teenagers and adult villagers belonging to Rejang tribe, were interviewed. They were composed of 34 males and 34 females, aged 15-60 years. The age, gender, family profession, education, hobby, time spent on electronic entertainment (electronic gadgets and TV), and time spent in plantations of each respondent was recorded. The photographs of plants were shown to each respondent who was then asked to identify the name and uses of each species of plant in the photographs. Setalaphruk and Price (2007), Pilgrim et al. (2008), Wiryono et al. (2017) and Wiryono et al. (2019) have also used photographs to test the ability of respondents to identify plants.

\section{Data analysis}

The names and uses of plant species were tabulated and analyzed descriptively. Correlation between age of each respondent and his or her knowledge of plant names and uses was tested using regression analyses, while the effect of gender on botanical knowledge was tested using t-tests. All the statistical analysis were conducted using Microsoft Office Excel program.

\section{RESULTS AND DISCUSSION}

\section{The diversity of useful plant species and types of uses}

The people of Rejang tribe in Kota Agung Village used 130 species of plants (Table 1) for 12 use categories, namely food (72 species), medicine (44), ornament (41), firewood (25), forage (10), construction (8), custom (7), hedge and fence (5), handicraft (4), coloring agent (4), cosmetic (3) and poison (2) (Figure 2). Other studies reported a variety of numbers of plant species used by villagers. Some communities used much more species, for example 218 species for eight use types in Bustamante, in the northern region in the State of Nuevo León, Mexico (Estrada-Castillón et al. 2018); 212 species for five categories of uses in Galimtignere, Adamawa, Cameroon (Himawa and Mapongmetsem 2018); 210 species for five use types in Karwar, Katanaka India, (Bhat et al. 2014), and 181 plant species just for medical purpose in
Poncokusumo District of East Java used (Batoro and Siswanto, 2017). Some others used much fewer species, for example 48 species for six types of uses in villages near Hiang Forest of Kerinci District, Jambi Province (Andesmora et al. 2017), 65 species for six uses in Kabena Island, Southeast Sulawesi Province (Rahayu and Rugayah 2010), and 79 species for ten purposes in Harapan Makmur Village, Central Bengkulu District (Wiryono et al. 2016). Relatively similar number of species were used by villagers of Leyte island of the Philippines, i.e., 122 species (Langenberger et al. 2009), 149 crop species for four uses by villagers near the Lore Lindu National Park, Central Sulawesi (Kellenbeck and Maass 2004). Based on the range of numbers provided above, the number of species used by the people of Rejang tribe in this study was considered as medium.

Most species of plants in this study were used as food, followed by medicines. Indeed, food is the primary need to sustain life, so in many regions the use of species as food ranked first among all uses of plants, such as found in villages inhabited by Cao Lan, a Tai-Speaking ethnic minority in Vietnam's northern mountains Vietnam (Timsuksai et al. 2015), in villages of southwest Uganda (Whitney et al. 2018), in Rajegwesi Village, Banyuwangi District, East Java (Pamungkas et al. 2013), among Baduy Dalam community in Banten (Wardah 2003), in villages near Hiang Forest of Kerinci District, Jambi Province (Andesmora et al. 2017), and Tebing Rambutan Village, near Kerinci Seblat National Park, Kaur District, Bengkulu Province (Wiryono et al. 2019).

After food plants, the next most frequently used plants were the medicinal plants, i.e., 44 out of 130 species. According to Rao and Rao (2006), medicinal plants were an important component in homegardens, next to food and fruit. Some rural communities used more plant species than in this study for medicines, i.e., 90 species by the Chakma community of Bangladesh (Roy et al. 2008), 181 species by villagers Poncokusumo District of East Java (Batoro and Siswanto, 2017), 127 species by the people of Serampas tribe in Kerinci Seblat National Park Jambi Province (Hariyadi and Ticktin 2012), and 250 species in Dayak village and adjoining forest in West Kalimantan (Caniago and Siebert 1998). Both the people of Serampas tribe and Dayak tribe are indigenous communities living close to natural forests, and so, they must have good knowledge of medicinal plants. These data show that despite the availability of modern medicines, people in the villages still use traditional medicines considerably. In fact, in many parts of the world, both modern and traditional medicines coexist (Rathore et al. 2015; Zank and Hanazaki 2017).

Ornamental plants ranked third in this study, based on the number of species used. In a study of homegardens in Vietnam (Timsuksai et al. 2015) ornamental plants ranked second, while in homegardens of Karwar, Karnataka, India, ornamental plants ranked first, indicating that the economic level of the community was relatively good (Bhat et al. 2014). In West Java, the transition of traditional homegardens into the modern ones was characterized by the increase in proportion of ornamental species (Iskandar et al. 2018; Prihatini et al. 2018). 
Table 1. List of useful plant species and types of uses by Rejang tribe people in Kota Agung Village, Kepahiang District, Bengkulu Province, Indonesia, according to interviews with key informants

\begin{tabular}{|c|c|c|c|}
\hline Local names & Scientific names & Plant families & Types of uses \\
\hline Air mancur & Russelia equisetiformis Schltdl. \& Cham & Scrophulariaceae & Ornamental \\
\hline Alpukat & Persea americana Mill. & Lauraceae & Food, medicines \\
\hline Anggrek & Phalaenopsis amabilis (L.) Blume & Orchidaceae & Ornamental \\
\hline Asam Jawa & Tamarindus indica $\mathrm{L}$. & Fabaceae & Firewood, food, medicines \\
\hline Asam kandis & Garcinia xanthochymus Hook. F .ex T. Anderson & Clusiaceae & Firewood, food \\
\hline Bambu mumbuh & Schizostachyum lima Merr. & Poaceae & Construction, food, handicraft \\
\hline Bambu air & Equisetum hyemale $\mathrm{L}$. & Equisetaceae & Ornamental \\
\hline Bawang dayak & Eleutherine palmifolia (L.) Merr & Iridaceae & Food, medicines \\
\hline Bayam & Amaranthus sp & Amaranthaceae & Food \\
\hline Belimbing & Averrhoa carambola $\mathrm{L}$. & Oxalidaceae & Food, ornamental \\
\hline Belimbing besi/wuluh & Averrhoa bilimbi $\mathrm{L}$. & Oxalidaceae & Food, medicines \\
\hline Binjai/kemang & Mangifera caesia Jack & Anacardiaceae & Firewood, food, medicines \\
\hline Bungastroberi & Saxifraga stolonifera Curtis & Saxifragaceae & Ornamental \\
\hline Buah naga & Selenicereus triangularis L. & Cactaceae & Food \\
\hline Bunga kertas/bugenvil & Bougainvillea glabra Choisy & Nyctaginaceae. & Ornamental \\
\hline Bungaceletup/ciplukan & Physalis angulata $\mathrm{L}$. & Solanaceae & Medicines \\
\hline Bungahebras & Gerbera crocea Kuntze & Asteraceae & Ornamental \\
\hline Buah paying & Pangium edule Reinw. & Salicaceae & Poison \\
\hline Bunga matahari & Helianthus annuus L. & Asteraceae & Food, ornamental \\
\hline Bunga mawar & Rosa graciliflora Rehder \& E.H.Wilson & Rosaceae & Ornamental \\
\hline Bunga piyung ayam & Celosia cristata $\mathrm{L}$. & Amarathaceae & Ornamental \\
\hline Bunga pudding puring & Codiaeum variegatum (L.) Rumph. ex A.Juss. & Euphorbiaceae & Ornamental \\
\hline Cabe rawit & Capsicum annuum L. & Solanaceae & Food \\
\hline Sukun & Artocarpus altilis (Parkinson) Fosberg & Moraceae & Food, medicines \\
\hline Dahlia & Dahlia pinnata Cav. & Asteraceae & Ornamental \\
\hline Daun bawang & Allium fistulosum $\mathrm{L}$. & Alliaceae & Food \\
\hline Daun salam & Syzygium polyanthusm (Wight) Walpers & Myrtaceae & Firewood, food, medicines \\
\hline Duku & Lansium domesticum (Osbeck) Sahni\&Bennet & Meliaceae & Food \\
\hline Durian & Durio zibethinus Rumph. Ex Murray & Malvaceae & Construction, firewood, food \\
\hline Gelombang Cinta & Anthurium plowmanii Croat & Araceae & Ornamental \\
\hline Hanjuang & Cordyline fruticosa (L.) A.Chev. & Asparagaceae & Custom/ritual, hegde \\
\hline Pacar air & Impatiens balsamina $\mathrm{L}$. & Balsaminaceae & Medicines, ornamental \\
\hline Jambu jamaika & Syzygium malaccense (L.) Merr. \& L.M.Perry & Myrtaceae & Food, ornamental \\
\hline Jambu air & Syzygium aqueum (Burm.f.) Alston & Myrtaceae & Firewood, food \\
\hline Jambu biji & Psidium guajava $\mathrm{L}$. & Myrtaceae & Food, medicines \\
\hline Jati & Tectona grandis Linn.F. & Lamiaceae & Construction, firewood \\
\hline Jembak & Agapanthus praecox Willd. & Amaryllidaceae & Food \\
\hline Jengkol & Archidendron pauciflorum (Benth.) I.C.Nielsen & Fabaceae & Firewood, food \\
\hline Jeruk purut & Citrus hystrix DC. & Rutaceae & Food, medicines \\
\hline Jeruk nipis & Citrus aurantiifolia (Christm.) Swingle & Rutaceae & Custom/ritual, food, ornamental \\
\hline Kacang mbing/kecipir & Psophocarpus tetragonolobus (L.) DC. & Fabaceae & Food \\
\hline Kacang panjang & Vigna unguiculata (L.) Walp. & Fabaceae. & Food \\
\hline Kakau/ coklat & Theobroma cacao $\mathrm{L}$. & Malvaceae. & Food \\
\hline Kaktus berduri & Cereus hildmannianus K.Schum. & Cactaceae & Ornamental \\
\hline Kaktus karang & Cereus jamacaru DC. & Cactaceae & Ornamental \\
\hline Kamboja & Adenium obesum (Forssk.) Roem. \& Schult. & Apocynaceae & Ornamental \\
\hline Kangkung & Ipomoea aquatica Forssk. & Convolvulaceae & Food, forage \\
\hline Kapuk & Ceiba pentandra (L.) Gaertn. & Malvaceae & Construction, firewood, handicraft \\
\hline Karet & Hevea brasiliensis (Willd. ex A.Juss.) Müll.Arg. & Euphorbiaceae & Firewood \\
\hline Katu & Sauropus rhamnoides Blume, Bijdr. 596 (1826) & Phyllanthaceae & Food \\
\hline Kayu res & Gliricidia sepium (Jacq.) Steud. & Fabaceae & Firewood \\
\hline Kedepoa & Ficus hispida L.f. & Moraceae & Medicines \\
\hline Kedondong & Spondias dulcis Parkinson & Anacardiaceae & Firewood, food \\
\hline Keladi & Colocasia esculenta (L.) Schott & Araceae & Food \\
\hline Kelapa & Cocos nucifera $\mathrm{L}$. & Arecaceae & $\begin{array}{l}\text { Construction, custom/ritual, } \\
\text { firewood, food, medicines }\end{array}$ \\
\hline Kembang sepatu & Hibiscus rosa-sinensis $\mathrm{L}$. & Malvaceae & Ornamental \\
\hline Kembang tunjung & Hippeastrum puniceum (Lam.) Voss & Amaryllidaceae & Medicines \\
\hline Kemiri & Aleurites moluccana (L.) Willd., Sp. Pl. 4 (1804) & Euphorbiaceae & Firewood, medicines \\
\hline Kemuning & Murraya paniculata (L.) Jack & Rutaceae & Ornamental \\
\hline Kencur & Kaempferia galanga (Linn.) & Zingiberaceae & Firewood, food \\
\hline Kenidai & Bridelia tomentosa Blume & Phyllanthaceae & Construction, medicines \\
\hline Kisik & Luffa acutangula (L.) Roxb. & Cucurbitaceae & Food \\
\hline Kopi & Coffea canephora Pierre ex A.Froehner & Rubiaceae & Firewood, food, medicines \\
\hline Kumis kucing & Orthosiphon aristatus (Blume) Miq. & Lamiaceae & Medicines, ornamental \\
\hline Kunyit & Curcuma longa $\mathrm{L}$. & Zingiberaceae & Color, food, medicines \\
\hline
\end{tabular}


Kunyit putih Kupu-kupu malam Lada/sahang Lengkuas

Lidah buaya

Lidah mertua

Mahoni

Mangga

Mawar

Meliki

Mengkudu

Merambung

Nanas

Nangka

Padi

Pakis

Paku binu

Pala

Pandan

Pare

Pecah piring

Pepaya

Perenggi

Petai

Petai Cina

Phihung batik

Pinang

Pisang

Pohon jarak

Pucuk merah

Pucung unji

Puding hitam

Putri malu

Rambutan

Rimbang

Ruku-ruku

Rumput Belanda

Rumput Jepang

Sabrina

Salak

Sawi

Sawo Manila

Scorbia

Selasi

Kapas

Serai

Siak-siak

Sedingin

Sirih

Soka

Srikaya

Strawberry

Suji

Suplir

Tebu

Tebutelur

Tanaman cocor bebek

Tembakau

Terong

Tomat cung

Tripuk/rumput

benggala

Tukupbumi

Ketumbar/tumbar laut

Ubi jalar

Ubi kayu
Curcuma mangga Valeton \& Zijp

Oxalis triangularis A.St.-Hil.

Piper nigrum L.

Alpinia galanga (L.) Willd

Aloe vera (L.) Burm.f.

Dracaena trifasciata (Prain) Mabb.

Swietenia macrophylla King

Mangifera indica $\mathrm{L}$.

Rosa $\times$ centifolia L.

Phyllanthus emblica $\mathrm{L}$.

Morinda citrifolia $\mathrm{L}$.

Vernonia arborea Scherb.Ham.

Ananas comosus (L.) Merr.

Artocarpus heterophyllus Lam., Encycl. 3 (1789)

Oryza sativa L.

Diplazium esculentum (Retz) Sw.

Cycas rumphii Miq.

Myristica fragrans Houtt.

Pandanus amaryllifolius Roxb. ex Lindl.

Momordica charantia $\mathrm{L}$.

Gardenia jasminoides J. Ellis.

Carica papaya $\mathrm{L}$.

Cucurbita moschata Duchesne

Parkia speciosa Hassk.

Leucaena leucocephala (Lamk.) de Wit, 1961

Perilla frutescens (L.) Britton

Areca catechu L.

Musa $\times$ paradisiaca $\mathrm{L}$.

Jatropha curcas L.

Syzygium myrtifolium Walp.

Etlingera elatior (Jack) R.M.Sm.

Graptophyllum pictum (L.) Griff.

Mimosa pudica L.

Nephelium lappaceum L.

Solanum torvum $\mathrm{Sw}$.

Ocimum tenuiflorum $\mathrm{L}$.

Ageratum houstonianum Mill.

Zoysia japonica Steud.

Tradescantia zebrina Bosse

Salacca zalacca (Gaertn.) Voss

Brassica juncea (L.) Czern.

Manilkara zapota (L.) P.Royen

Euphorbia milii Des Moul.

Ocimum basilicum L.

Gossypium hirsutum L.

Cymbopogon citratus (DC.) Stapf

Ophiopogon japonicus (Thunb.) Ker

Kalanchoe pinnata (Lam.) Pers.

Piper betle $\mathrm{L}$.

Ixora coccinea $\mathrm{L}$.

Annona muricata L.

Fragaria $\times$ ananassa (Duchesne ex Weston)

Duchesne ex Rozier

Dracaena angustifolia (Medik.) Roxb.

Adiantum trapeziforme $\mathrm{L}$.

Saccharum officinarum $\mathrm{L}$.

Saccharum spontaneum $\mathrm{L}$.

Kalanchoe ceratophylla Haw.

Nicotiana tabacum L.

Solanum melongena $\mathrm{L}$.

Solanum lycopersicum L.

Urochloa maxima (Jacq.) R.D.Webster

Mikania micrantha Kunth

Coriandrum sativum $\mathrm{L}$.

Ipomoea batatas (L.) Lam.

Manihot esculenta Crantz
Zingiberaceae

Oxalidaceae

Piperaceae

Zingiberaceae

Asphodelaceae

Asparagaceae

Meliaceae

Anacardiaceae

Rosaceae

Phyllanthaceae

Rubiaceae

Asteraceae

Bromeliaceae

Moraceae

Poaceae

Aspleniaceae

Cycadaceae

Myristicaceae

Pandanaceae

Cucurbitaceae

Rubiaceae

Caricaceae

Cucurbitaceae

Fabaceae

Fabaceae

Lamiaceae

Arecaceae

Musaceae

Euphorbiaceae

Myrtaceae

Zingiberaceae

Acanthaceae

Fabaceae

Sapindaceae

Solanaceae

Lamiaceae

Asteraceae

Poaceae

Commelinaceae

Arecaceae

Brassicaceae

Sapotaceae

Euphorbiaceae

Lamiaceae

Malvaceae

Poaceae

Asparagaceae

Crassulaceae

Piperaceae

Rubiaceae

Annonaceae

Rosaceae

Asparagaceae

Pteridaceae

Poaceae

Poaceae

Crassulaceae.

Solanaceae

Solanaceae

Solanaceae

Poaceae

Asteraceae

Apiaceae

Convolvulaceae

Euphorbiaceae
Food, medicines

Ornamental

Food

Food

Cosmetic, ornamental

Ornamental

Construction, firewood

Firewood, food

Ornamental

Hedge, ornamental

Medicines

Construction, firewood

Food

Firewood, food

Food

Food

Food, medicines

Firewood, food, medicines

Color

Food

Medicines

Food, medicines

Food

Firewood, food

Firewood, food

Ornamental

Color, construction, costum,

handicraft

Food, forage, medicines

Medicines

Ornamental

Food

Medicines

Ornamental

Firewood, food, medicines

Food, medicines

Medicines, ornamental

Medicines

Ornamental

Ornamental

Food

Food

Food

Ornamental

Medicines

Ornamental

Food, medicines

Poison

Medicines

Custom/ritual, food, medicines

Ornamental

Firewood, food, medicines, ornamental

Food, ornamental

Color, food, hedge

Ornamental

Food

Food

Medicines, ornamental

Medicines

Food

Food

Forage

Forage

Food, medicines

Food

Food 


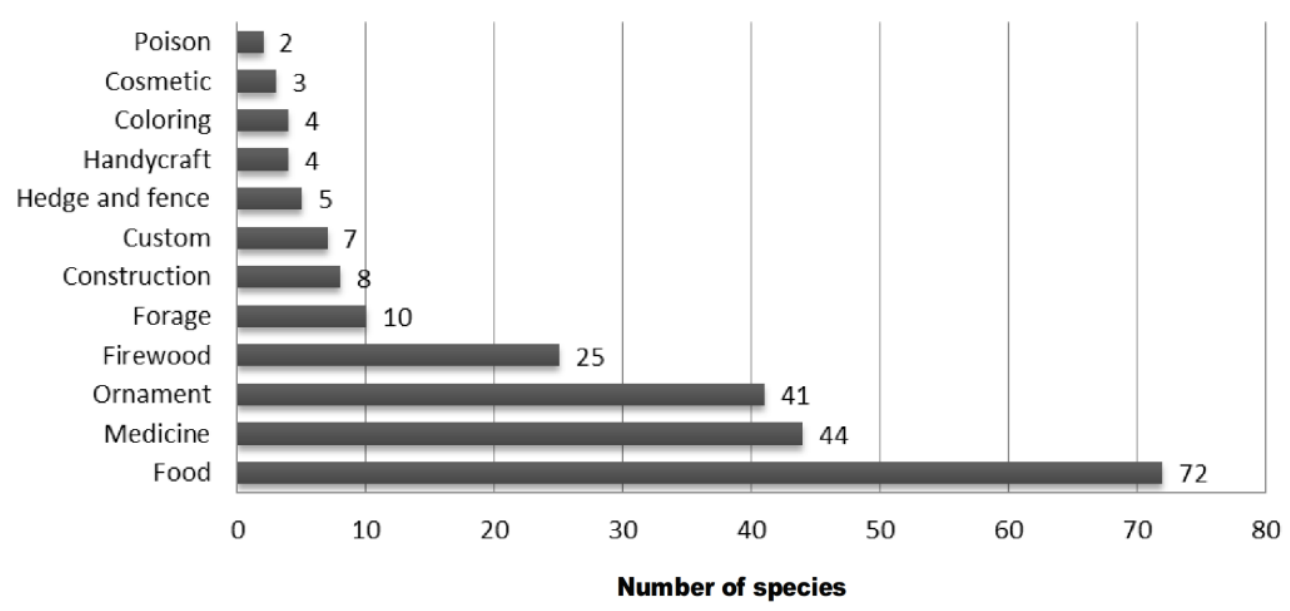

Figure 2. Number of species used for each of the different use categories by Rejang tribe people in Kota Agung Village, Kepahiang District, Bengkulu Province, Indonesia

Although the number of useful species varied greatly among the traditional gardens, in general, the diversity of useful plant species in traditional gardens is much higher that of modern plantations. Therefore, the traditional gardens may serve as biodiversity conservation areas, while at the same time, provide economic benefits to the people (Rao and Rao 2006; Udawata and Godsey 2010). In fact, an agroforestry system may provide a broad range of environmental services, such as biodiversity conservation, carbon sequestration, soil enrichment, and air and water quality maintenance (Jose 2009). Due to its multifunction, an agroforestry system is considered as the sustainable practice of agriculture. However, many traditional gardens have been converted into commercial ones due to the penetration of market economy which causes drastic changes in their species composition. In Sukapura Village of West Java, Prihatini et al. (2018) found that traditional gardens were composed of 161 species of plants, while the commercial gardens had only 61 species, dominated by commercial vegetable crops. Although the commercial gardens yield high economic revenue, they lose some of their ecological functions. Similar cases also happened in western Ethiopia (Woldeyes et al. 2016), where the structure and composition of homegardens had drastically changed because commercial introduced crops replaced the indigenous ones, reducing the biodiversity and the sustainability of homegardens. Another study in Kurunegala District of Srilanka (Korale-Gedera et al. 2012) also showed that commercial gardens had lower plant diversity than the traditional ones.

\section{Correlation between age and knowledge of plant names and uses}

The age of a respondent was positively correlated with his or her knowledge of plant names (with correlation coefficient or r-value of 0.545 , p-value of 1.51E-06) and plant uses (with r-value of 0.715 and p-value of 7.73E-12), meaning that older people were more knowledgable than the young ones (Figures 3 and 4). The correlation was moderately strong, and statistically highly significant. The result of this study confirms the previous studies that showed the decline of local botanical knowledge among young generations, as happening in rural community of Bananal, Mato Grosso, Brazil (Miguéis et al. 2019), in Garifuna, Nicaragua (Coe and Anderson 1996), in Western Himalaya (Uniyal et al. 2006), in Sukamandi Village of Subang, West Java, (Suryana et al. 2018), in Tanjung Terdana village, Central Bengkulu (Wiryono et al. 2017), and Tebing Rambutan Village (Wiryono et al. 2019). Indeed, the decline of botanical knowledge worldwide has become a serious concern among ethnobotanists worldwide (Ramirez 2007; Aswani et al. 2018). This decline of traditional knowledge may have consequences, ranging from the relatively less serious, such as the risk of injury and poisoning among children due to contact with harmful plants (Cuadra et al. 2012) to the more serious ones, i.e. the very survival of humans (Aiona et al. 2007).

The economic development which leads to conversion of high-biodiversity natural forests and traditional gardens into the low-biodiversity forest plantations and commercial gardens, has generally been blamed for the decline of botanical knowledge among the young generation (Aiona et al. 2007; Ramirez 2007). Some studies, however, investigated in more detail the aspects of economic development which cause the loss of such knowledge. In the community of Zapotecs, Mexico, with the economic development, many children went to school and, therefore, did not have enough time to help their parents collecting plants in the gardens, so they no longer retained the botanical knowledge (Saynez-Vazquez et al. 2016). In addition, the language used in school was not the same as that used to convey botanical knowledge. In another study, in Doñana, Spain, the farmers lost their traditional ecological knowledge because they adopted modern knowledge which came with the modern farming as a result of market economy penetration (Gómez-Baggethun and Reyes-Garcia, 2013). The loss of botanical knowledge, however, occurred not only in young people. In Kolo 
District of southeastern Niger, Ayantunde et al. (2008) found that the knowledge of plant names increased with age until 50 years old, then, after this age, the knowledge slightly declined, because the old men shifted the responsibilities of herding to the younger ones.

The causes for decline of botanical knowledge among the young people of the Rejang tribe in this study were not clear. Although there was positive correlation between the time spent in the plantation and the knowledge of plant names, the correlation coefficient was low (only 0.345). Conversely, there was also a negative correlation between time spent on electronic entertainment and knowledge of plants, but the coefficient of correlation was only 0.399 . Table 2 shows that female respondents who spent less time in the plantations and more time for electronic entertainment had higher botanical knowledge than male respondents who spent more time in the plantations and for electronic entertainment. The time spent in the plantations did not have strong correlation with the botanical knowledge presumably because the plantations, which were coffee plantations, had low plant diversity. Further studies are needed to know the factors causing the loss of botanical knowledge among the young generation in Kota Agung village.

Loss of botanical knowledge, however, did not happen in some communities. For example, the young migrants from the Dominican Republic who lived in New York maintained their knowledge of traditional food medicines because they still consumed them (Vandebroek and Balick 2012). Another study in Bolivia, reported that the indigenous people of Tsimane managed to maintain their traditional ecological knowledge (TEK) because they still practiced farming and sold farm products in traditional way (Gómez-Baggethun and Reyes-Garcia, 2013). In the Andean Highland of Peru and Bolivia, the farmers taught their knowledge of medicinal plants to their children by involving them in handling the medicinal plants, so the young people did not lose the knowledge of medicinal plants (Mathez-Stiefel et al. 2012).

\section{Effect of gender on knowledge of plant names and uses}

The female respondents of Rejang tribe in this study had significantly more knowledge of plant names than the males (Table 2). This result was contradictory to the previous study in Semende tribe, Kaur District in Bengkulu (Wiryono et al. 2019), in which males had better botanical knowledge presumably due to their longer time spent in gardens or agricultural plantations located within the conservation forest which had high plant diversity. The men of Semende tribe, therefore, had more chance of interacting with various plant species. In Rejang tribe, the men also spent significantly more time in plantations than the women. However, the plantations of Rejang tribe were a single species plantations, i.e., coffee plantations. Therefore, the men might spend less time interacting with a high diversity of plants in their homegardens.

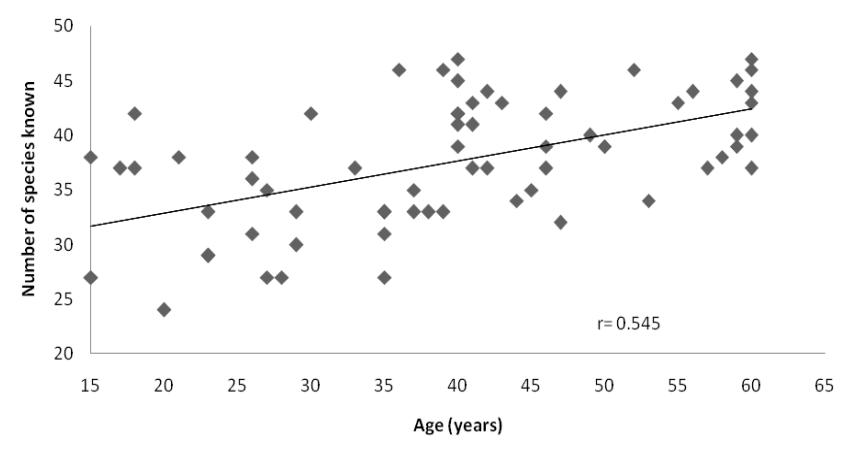

Figure 3. Correlation between the age of respondents and the number of plant species identified correctly by them

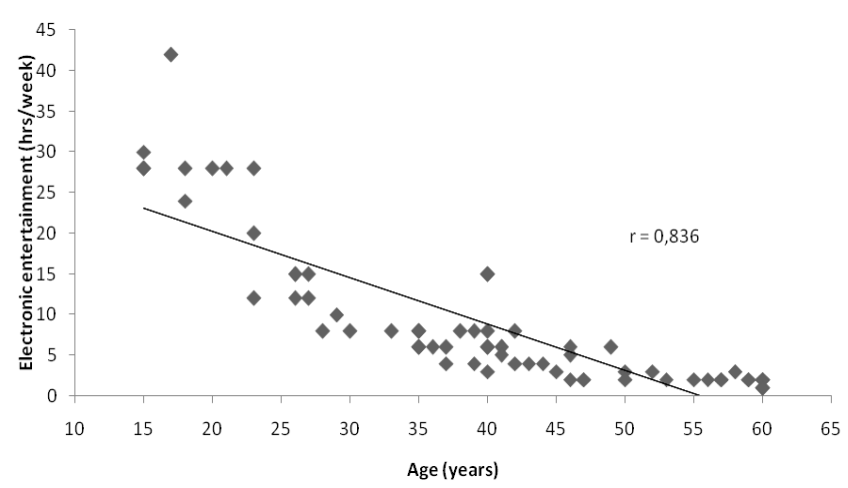

Figure 6. Correlation between time spent for electronic entertainment and age of respondents
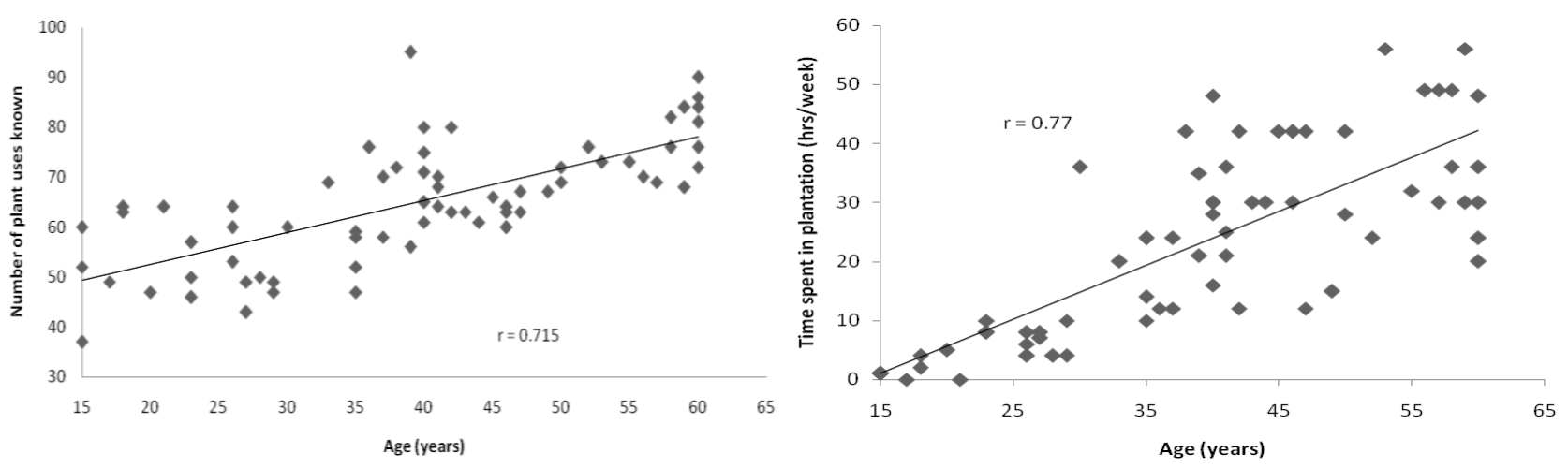

Figure 5. Correlation between age of respondents and time spent in the plantations 
Table 2. The average number of plant names and uses identified by respondents according to their gender

\begin{tabular}{lcc}
\hline & \multicolumn{2}{c}{ Gender } \\
& Male & Female \\
\hline Number of plant species known & $34.62 \mathrm{a}$ & $40.35 \mathrm{~b}$ \\
Number of plant uses known & $63.56 \mathrm{a}$ & $66.53 \mathrm{a}$ \\
Time spent in the plantations (hrs/week) & $27.82 \mathrm{a}$ & $19.03 \mathrm{~b}$ \\
Time spent on electronic entertainment & $7.97 \mathrm{a}$ & $10.41 \mathrm{a}$ \\
\hline
\end{tabular}

Note: Numbers in the same row followed by the same letter are not significantly different at 0.05 significance level

Another plausible cause is the job separation based on gender, which assigns women mostly domestic works (Nurlian and Daulay 2008). The plant species which had been identified by respondents in this study were mostly from homegardens used for food, medicinal and ornamental purposes. Because men in this study spent more time in plantations, the care of plants in homegardens was by women. This hypothesis, however, needs to be verified and confirmed by further studies.

Some ethnobotanical studies have analyzed the effect of gender on botanical knowledge, but there is no general conclusion. Some studies showed that botanical knowledge was not affected by gender, while others found otherwise, but the effect of gender could be the opposite from one another (Torres-Avilez et al. 2016). In Grosses Walsertal, Vorarlberg, the very western province of Austria, women knew more medicinal plants because they are in charge of food and medicine related tasks in the households, while the men usually work far from the house (Schunko et al. 2016). Similarly, women also knew more medicinal plants than men in rural communities near Chapada Diamantina National Park in Bahia, Brasil, (Voeks 2007) because women's job was taking care of the family health and maintaining the swiddens and home gardens. Conversely, however, the people in Zegie Peninsula, Northwestern Ethiopia, males knew more medicinal plants than females because in this community the traditional knowledge is passed from the father to his first son (Teklehaymanot and Giday. 2007). Similarly, in the community of Fulni-ô in north-eastern Brazil also, males knew more medicinal plants than females (De Albuquerque et al. 2011).

Sometimes, both males and females had considerable botanical knowledge but for different types of plant uses due to their job differences. In Garifuna, Nicaragua, females knew more food and medicinal plants, while males knew more field crops and wild plants (Coe and Anderson 1996). In southwestern Niger, men had better knowledge of forage, construction, and firewood plants than women, but there was no difference between them in the knowledge of medicinal and food plants (Ayantunde et al. 2008). In other studies, there was no difference between men and women in the botanical knowledge, such as in the community near Parnaiba Delta Environmental area in Brazil (Sousa et al. 2012), among the forestry students of Bengkulu University, in Bengkulu Province (Wiryono and Nurliana 2011), among the Serawai tribe of Bengkulu (Putra et al. 2012), and the villagers of Tanjung Terdana, Central Bengkulu (Wiryono et al. 2017).

\section{ACKNOWLEDGEMENTS}

We express our gratitude to the University of Bengkulu, Indonesia which has funded this study, and the anonymous reviewer who has given suggestions for the improvement of this article.

\section{REFERENCES}

Aiona K, Balick MJ, Bennett BC, Bridges K, Burney DA, Burney LP. 2007. Ethnobotany the science of survival: a declaration from Kaua' $i$. Econ Bot 61 (1): 1-2.

Andesmora EV, Muhadiono, Hilwan I. 2017. Ethnobotany Hiang Indigenous Forest, Kerinci. J Trop Life Sci 7 (2): 95-101.

Aswani S, Lemahieu A, Sauer WHH. 2018. Global trends of local ecological knowledge and future implications. PLoS ONE 13 (4): e0195440. DOI: 10.1371/journal.pone.0195440

Ayantunde AA, Briejer M, Hiernaux P. 2008. Botanical knowledge and its differentiation by age, gender and ethnicity in Southwestern Niger. Hum Ecol 36: 881. DOI: 10.1007/s10745-008-9200-7

Batoro J, Siswanto D. 2017. Ethnomedicinal survey of plants used by local society in Poncokusumo district, Malang, East Java Province, Indonesia. Asian J Med Biol Res 3 (2): 158-167. DOI: 10.3329/ajmbr.v3i2.33563

Bhat S, Bhandary MJ, Rajanna L. 2014. Plant diversity in the homegardens of Karwar, Karnataka, India. Biodiversitas 15 (2): 229235.

BPS Kepahiang. 2018. Kepahiang Regency in figures. Statistic Agency of Kepahiang. [Indonesian]

Caniago I, Siebert SF. 1998. Medicinal plant ecology, knowledge and conservation in Kalimantan, Indonesia. Econ Bot 52: 229-250. DOI: 10.1007/BF02862141

Colchester M, Boscolo M, Contreras-Hermosilla. 2006. Justice in the Forest: Rural Livelihoods and Forest Law Enforcement. CIFOR, Bogor. Indonesia.

Coe FG, Anderson GJ. 1996. Ethnobotany of the Garifuna of Eastern Nicaragua. Econ Bot 50: 71-107.

Cuadra VP, Cambi V, Ruda MA. 2012. Consequences of the Loss of Traditional Knowledge: The risk of injurious and toxic plants growing in kindergartens. Ethnobot Res App 10: 077-094.

Darmawan R, Klasen S, Nuryanto N. 2016. Migration and deforestation in Indonesia, EFForTS Discussion Paper Series, No. 19, Collaborative Research Centre 990 "EFForTS, Ecological and Socioeconomic Functions of Tropical Lowland Rainforest Transformation Systems (Sumatra, Indonesia)", Göttingen. http: //nbn-resolving.de/urn: nbn: de: gbv: 7-webdoc-3967-7

De Albuquerque UP, Soldati GT, Sieber SS, Ramos MA, De Sá JC, De Souza LC. 2011. The use of plants in the medical system of the Fulniô people (NE Brazil): a perspective on age and gender. J Ethnopharmacol 133 (2): 866-873. DOI: 10.1016/j.jep.2010.11.021

Estrada-Castillón E, Villarreal-Quintanilla JA, Rodríguez-Salinas MM. 2018. Ethnobotanical Survey of Useful Species in Bustamante, Nuevo León, Mexico. Hum Ecol 46 (1): 117-132. DOI: 10.1007/s10745-017-9962-x

FAO. 2016. Global forest assessment 2015. How are the World' Forests Changing? FAO. Rome.

Gómez-Baggethun E, Reyes-García V. 2013. Reinterpreting change in traditional ecological knowledge. Hum Ecol 41: 643-647.

Hariyadi B, Ticktin T. 2012. Uras: medicinal and ritual plants of Serampas, Jambi Indonesia Ethnobot Res Appl 10: 133-149.

Hidayat S, Fijridiyanto IA. 2002. Traditional plant use in Gunung Halimun National Park. Berita Biologi 6 (1): 125-130.[Indonesian]

Himawa Y, Mapongmetsem PM. 2018. Crop diversity and typology of homegardens of Galimtignere (Adamawa, Cameroon). Intl J Agrofor Silvicult 6 (2): 343-353.

Iskandar J, Iskandar BS, Partasasmita R. 2018. Review. The impact of social and economic change on domesticated plant diversity with special reference to wet rice and homegarden farming of West Java, Indonesia. Biodiversitas 19 (2): 565-577. DOI: 10.13057/biodiv/d190227

Iskandar J, Iskandar BS. 2016. Ethnoecology and management of agroecosystems undertaken by people of Karangwangi Village, 
Cidaun Sub-district, South Cianjur Selatan, West Java. Journal Biodjati 1 (1): 1-12. [Indonesian]

Jose S. 2009. Agroforestry for ecosystem services and environmental benefits: an overview. Agroforest Syst 76: 1-10. DOI 10.1007/s.10457-009-9229-7.

Kehlenbeck K, Maass B. 2004. Crop diversity and classification of homegardens in Central Sulawesi, Indonesia. Agroforest Syst 63: 53. DOI: $10.1023 / \mathrm{B}$ : AGFO.0000049433.95038.25

King KFS. 1987. The history of agroforestry. In: Stepler HA, Nair PKR (eds.). Agroforestry a Decade of Development. ICRAF, Nairobi, Kenya.

Korale-Gedera P, Weerahewa J, Pushpakumara G. 2012. Commercial orientation and its effects on plant diversity in home gardens: an empirical investigation of rural households in Sri Lanka. Sri Lankan J Agric Econ 14 (1): 17-42.

Langenberger G, Prigge V, Martin K, Belonias B, Sauerborn J. 2009. Ethnobotanical knowledge of Philippine lowland farmers and its application in agroforestry. Agrofor Syst 7: 173-194.

Mathez-Stiefel, SL, Brandt R, Lachmuth S. 2012 Are the young less knowledgeable? local knowledge of natural remedies and its transformations in the Andean Highlands. Hum Ecol 40: 909. DOI: $10.1007 / \mathrm{s} 10745-012-9520-5$

Miguéis GDS, da silva RH, Júnior GAD. 2019. Plants used by the rural community of Bananal, Mato Grosso, Brazil: Aspects of popular knowledge. PlosOne. DOI: 10.1371/journal.pone.0210488

Nurlian, Daulay H. 2008. Kesetaraan gender dalam pembagian kerja pada keluarga petani ladang (studi kasus analisa isu gender pada keluarga petani ladang di Desa Cot Rambong, Kecamatan Kuala, Kabupaten Nagan Raya, NAD). Jurnal Harmoni Sosial 2 (2): 76-82. [Indonesian]

Pamungkas RN, Indriyani S, Hakim L. 2013. The ethnobotany of homegardens along rural corridors as a basis for ecotourism planning: a case study of Rajegwesi village, Banyuwangi, Indonesia. J Biodiv Environ Sci 3 (8): 60-69.

Pilgrim SE, Cullen LC, Smith DJ, Pretty J. 2008. Ecological knowledge is lost in wealthier communities and countries. Environ Sci Technol 42 (4): 1004-1009.

Prihatini J, Iskandar J, Partasasmita R, Nurjaman D. 2018. The impacts of traditional homegarden conversion into the commercial one: a case study in Sukapura Village of the upstream Citarum watershed, West Java, Indonesia. Biodiversitas 19 (5): 1926-1940

Putra RA, Wiryono, Aprianto E. 2012. Studi Etnobotani Suku Serawai di Kelurahan Sukarami Kecamatan Selebar Kota Bengkulu. Naturalis 1 (3): 214-224. [Indonesian]

Quinlan MB, Quinlan RT. 2007. Modernization and medicinal plant knowledge in a Caribbean horticultural village. Med Anthropol Q New Ser 21 (2): 169-192.

Rahayu M, Rugayah. 2010. Local knowledge and utilization of plants by local communities Kabaena Island, Southeast Sulawesi. Berita Biologi 10 (1): 67-75. [Indonesian]

Ramirez CR. 2007. Ethnobotany and the loss of traditional knowledge in the $21^{\text {st }}$ century. Ethnobot Res App 5: 245-247.

Rao MR, Rao BRR. 2006. Medicinal plants in tropical homegardens. In Kumar BM, Nair PKR (eds.). Tropical Homegardens: A Time-Tested Example of Sustainable Agroforestry. Springer, Netherlands.

Rathore S, Tiwari JK, Malik ZA. 2015. Ethnomedicinal survey of herbaceous flora traditionally used in health care practices by inhabitants of Dhundsir gad watershed of Garhwal Himalaya, India. Global J Res Med Plants Indigen Med 4 (4): 65-78

Roy S, Uddin MZ, Hassan MA, Rahman MM. 2008. Medico-botanical report on the Chakma community of Bangladesh. Bangladesh J Plant Taxon 15 (1): 67-72.

Saxon E, Roquemore. 2011. Palm Oil. In: Boucher D, Elias P, Lininger K, et al (eds.). The root of the problem. What is the driving force of tropical deforestation today? Tropical Forest and Climate Initiative. Union of Concerned Scientists, Cambridge, MA.

Saynes-Vásquez A, Vibrans H, Vergara-Silva F, Caballero J. 2016. Intracultural differences in local botanical knowledge and knowledge loss among the Mexican Isthmus Zapotecs. PLoS One 11 (3): e0151693. DOI: 10.1371/journal.pone.0151693
Schunko C, Grasser S, Vogl CR. 2016. Intracultural variation of knowledge about wild plant uses in the Biosphere Reserve Grosses Walsertal (Austria). J Ethnobiol Ethnomed 8 (23). DOI: 10.1186/1746-4269-8-23

Setalaphruk C, Price LL. 2007. Children's traditional ecological knowledge of wild food resources: a case study in a rural village in Northeast Thailand. J Ethnobiol Ethnomed 3: 33-44.

Soemarwoto O. 1983. Ekologi, lingkungan hidup dan pembangunan. Penerbit Djambatan. Jakarta.

Sousa RDS, Hanazaki N, Lopes JB, de Barros RFM. 2012. Are gender and age important in understanding the distribution of local botanical knowledge in fishing communities of the parnaíba delta environmental protection area?. Ethnobot Res Appl 10: 551-559.

Suryana, Iskandar J, Parikesit, Partasasmita R. 2018. Ethnobotany of tree ferns in Pasir Menyan Hamlet, Sukamandi VillageSubang, West Java, Indonesia. Biodiversitas 19 (6): 2044-2051.

Teklehaymanot T, Giday M. 2007. Ethnobotanical study of medicinal plants used by people in Zegie Peninsula, Northwestern Ethiopia. J Ethnobiol Ethnomed 3 (12). DOI: 10.1186/1746-4269-3-12.

Timsuksai P, Nguyen DT, Rambo AT. 2015. Homegardens of the Cao Lan, a Thai-speaking ethnic minority in Vietnam's Northern Mountains. Southeast Asian Stud 4 (2): 365-383.

Tongco Ma D. 2007. Purposive sampling as a tool for informant selection. Ethnobot Res Appl 5: 147-158.

Torres-Avilez W, de Medeiros PM, Albuquerque UP. 2016. Effect of gender on the knowledge of medicinal plants: systematic review and meta-analysis. Evid Based Compl Alternat Med. DOI: $10.1155 / 2016 / 6592363$

Udawatta RP, Godsey LD. 2010. Agroforestry comes of age: putting science into practice. Agroforest Syst 79: 1-4. DOI 10.1007/s10457010-9296-9

Uniyal SK, Singh KN, Jamwal P, Lal B. 2006. Traditional use of medicinal plants among the tribal communities of Chhota Bhangal, Western Himalaya. J Ethnobiol Ethnomed 2: 14. DOI: 10.1186/17464269-2-14.

Vandebroek I, Balick MJ. 2012. Globalization and loss of plant knowledge: Challenging the paradigm. PLoS One 7 (5): e37643. DOI: 10.1371/journal.pone.0037643

Voeks. 2007. Are women reservoirs of traditional plant knowledge? Gender, ethnobotany and globalization in northeast Brazil. Singapore J Trop Geogr 28: 7-20.

Wardah. 2003. Pemanfaatan keanekaragaman sumberdaya tumbuhan oleh masyarakat Badudy Dalam sekitar Gunung Kendeng Selatan, Kabupaten Lebak, Banten. Berita Biologi 5 (6): 679-689. [Indonesian]

Whitney CW, Luedeling E, Tabuti JRS. 2018. Crop diversity in homegardens of southwest Uganda and its importance for rural livelihoods.Agric Hum Values 35 (2): 399-424. DOI: 10.1007/s10460-017-9835-3

Wiryono, Japriyanto, Erniwati. 2017. The diversity of locally utilized plants and local botanical knowledge in Central Bengkulu District, Bengkulu Province, Indonesia. Biodiversitas 17 (2): 1589-1595.

Wiryono, Nurliana S. 2011. The knowledge of Bengkulu University's forestry students of tree diversity in their campus. Nusantara Biosci 22: 98-103.

Wiryono, Puteri VNU, Senoaji G. 2016. The diversity of plant species, the types of plant uses and the estimate of carbon stock in agroforestry system in Harapan Makmur Village, Bengkulu, Indonesia. Biodiversitas 7 (1): 249-255.

Wiryono, Wanandi Y, Ilahi AK, Deselina, Senoaji G, Siswahyono. 2019. The local knowledge of the plant names and uses by Semende tribe people in Kaur District, Bengkulu Province, Indonesia. Biodiversitas 20 (3): 754-761.

Woldeyes F, Astaw Z, Demissew S, Roussel B. 2016. Homegardens (Aaloos-gad) of the Basket People of Southwestern Ethiopia: Sustainable ecosystem characterizing a traditional landscape. Ethnobot Res Appl 14: 549-563.

Zank S, Hanazaki N. 2017. The coexistence of traditional medicine and biomedicine: A study with local health experts in two Brazilian regions. PLoS ONE 12 (4): e0174731. DOI: 10.1371/journal.pone.0174731. 